\title{
A Resource Based Perspective: Impact of IT Capabilities on Superior Performance Considering the Role of Information Intensity
}

\author{
Dr. Anwar Yahia Shams Eldin \\ Assistant Professor \\ Department of Business Administration \\ Faculty of Art and Science -Tathleeth \\ University of Bisha \\ Kingdom of Saudi Arabia
}

\begin{abstract}
A company's resources and capabilities are considered as a sources of superior performance. However, most literature has not clearly linked IT capabilities to superior performance. This paper, therefore, uses the RBV (resource based view) to explore the relationship between company's IT capabilities and superior performance in Sudanese banking and insurance sectors, through comprehensive model of IT capabilities, which is narrowing define IT capabilities. Moreover, discussing the impacts of an internal factor the information intensity in this relation. Based on a questionnaire collected from IT employees and middle managers the findings of this study indicates that information intensity can be considered as predictor's factors in the relationship between IT capabilities and superior performance. Moreover, the results show that the different dimensions of IT capabilities have different effects on superior performance. Additionally, the results show how IT capabilities affects the competitiveness of Sudanese's banking and insurance sectors, and explore the source of advantage. Thus, provided RBV with certain limits, which required for a good theory.
\end{abstract}

Keywords: IT Capabilities, Superior Performance, Information Intensity, RBV.

\section{Introduction}

According to resource based perspective (RBV) the accumulation of resources and capabilities that have certain characteristics such as: valuable to those of rivals; and difficult to be imitated or substituted; rare (Wade and Hulland, 2004; Barney, 1991); can be responsible for creating and sustaining competitive advantage (Wade and Hulland, 2004; Barney, 1991; Crook, Ketchen, David, Combs, and Todd, 2008, Hanningtone, Struwig, and Smith,2013) in term of superior performance (Barney, 1991; Ma, 1999; Denrell, Fang, and Zhao 2013). Superior performance is denoted as above average performance (Porter, 1985; Jones and Hill, 2004) or above median of the performance of the industry; Denrell, Fang, and Zhao, 2013).

More or less most of previous RBV studies investigated the relationships among IT and organizational capabilities and performance or superior performance (Tallon and Kraemer, 2003; Tian et al., 2009; Bi et al., 2010; Bharadwaj, 2000; Tallon, 2007; Mithas et al., 2005), concentrated on some capabilities (see Masrek and Jusoff, 2009; Byrd, and Byrd, 2010; Elkordy,2014) or ignoring the factors that may affect these relations (e.g Wade and Hulland, 2004; Keramat et al., 2007). This, leads to narrowing down the focus to reveal the scope of the business value of IT, due to the risk of commonality shared by, and the interaction among these specific IT capabilities (Lu \& Ramamurthy, 2011).

* This article was submitted in February 2016, and accepted for publishing in May 2016. 
Moreover, the microstructures of organizational capabilities and how they are established and grow are unclear. Furthermore, the techniques of identifying, assessing, and developing resource and capability are underdeveloped (Grant, 2005). Nevertheless, the measure of IT capabilities suffers because it is 'monolithic' and does not distinguish between different dimensions (Byrd and Byrd, 2010).

This raises the need of typologies that would classify resources/capabilities in order to recognize their contribution to the performance or sustainability of competitive advantage. Besides, make a clear distinction between the capacity building mechanisms (capabilities at different levels), acquiring and possessing mechanism (which includes both resources and capabilities) versus the processes of deploying that capacity, to show how RBV sustains competitive advantage or performance (Kraaijenbrink and Spender and Aard, 2009).

Some recent studies use the RBV to examine the competitive value of IT capabilities to business through a comprehensive model of IT capabilities ( see Bhatt \& Grover, 2005; Ravichandran and Lertwongsatien, 2005; Bharadwaj; 2000; Santhanam and Hartono; 2003; Zhang \& Sarker, 2008; Lu \& Ramamurthy, 2011). The findings from these studies generally indicate that IT capabilities can contribute to better firm performance and to competitive advantage (Chen et al., 2014).

On the other hand, many authors indicate to superior performance (see Barney, 1991; and Peteraf, 1993; Denrell, Fang, and Zhao 2013). Most studies select some performance indicators to measure superior performance (e.g. Barney, 1991; Peteraf, 1993; Grant, 1991; Denrell, Fang, and Zhao 2013). Some scholars, criticized the use of single performance measures for measuring superior performance (M. deChabert, 1998; Wiggins, 1997; Narver\& Slater, 1990) despite of that, there is no agreement about how to measure superior performance (see Denrell, Fang, and Zhao 2013).

According to the RBV scholars, the relationships between resource/capabilities and firm performance at the firm level are the sum of results of different effects of different resources/capabilities (Ray, Barney, \& Muhanna, 2004). These results in differences in performance between firms that deliver both superior and low value resources \capabilities and those that lack both resources\capabilities (Henderson \& Cockburn, 1994). Consequently, some researchers propose that deviations in the level of dependant and independent variables could be controlled potency by confounding factors (Wade and Hulland, 2004; Keramati, 2007). Accordingly, to gain a comprehensive model about how IT impacts business value these factors must be studied (Zhu, Kraemer, $\mathrm{Xu}$, and Dedrick, 2004; Wiengarten, Humphreys, and Cao McHugh, 2013).

Organizational factors include information intensity, firm size and management commitments (Makau et al., 2013). One of these factors is organizational factors which may affect the way that organizations use and benefit from information systems is information intensity (Yap, 1990). Few studies have explored the impacts of information intensity to gain business value in terms of superior performance (Hu and Quan, 2003).

Accordingly, it can be concluded that there are limited models that are based on RBV, which have a comprehensive view about the mechanism through which IT capabilities impact, superior performance in the literature that take into consideration the factors that affect these relations.

This study used a comprehensive model that based on RBV to look inside the "black box" of IT capabilities to determine if the different dimensions have different effects on the superior performance. Additionally, to explore how these different dimensions produce distinct effects on superior firm's performance of insurance and banking sector in Sudan, and discuss the effects of some organizational factors on this relation, specifically, information intensity.

The importance of measuring the mechanisms through which IT capabilities impacts superior performance lies in the importance of formulation (and reformulation) strategy necessary for attaining a sustainable 
competitive advantage (Grant, 2005). Besides, it can be used to know how a unique capability can contribute to superior performance compared to the competitors (Bharadwaj, 2000).

Moreover, the use of a comprehensive model of IT capabilities enables to invert the similarities and synergies among different IT resources and assets (Chen et al., 2014). This is also important for managers to help them prioritize capabilities and optimally allocate investments to develop a superior performance. It is also, important for researchers to clarify the criteria or conditions or factors in which particular capabilities result in superior performance. Thus, provides the RBV with boundaries which required for good theory (Bacharach, 1989).

\section{Superior Performance}

Porter (1985) utilizes the term superior performance to indicate to a firm which has above average performance in the industry, which is accomplished through execution generic strategies that are sustainable. According to Barney (1991) and Peteraf (1993) superior performance can be accomplished when a firm has a competitive advantage that is creating more economically and/or better to fulfil client demands.

More or less of the RBV writers (e.g. Barney, 1991; Peteraf, 1993; Grant, 1991) measured superior performance in term of rent, which is assessed in term of profitability. Barney (2002) suggests both rent and profit. Fahy (2000) measured superior performance in term of, market performance, sales performance. Woodruff (1997) reviewed some RBV scholar's metrics for measuring superior performance, which includes the following metrics: customer retention and sales growth, and profitability. Porter (1985) has measure superior performance by profit and market share. Narver and Slater (1990) assessed the long term firm superior performance through three profitability measures: relative return on investment in the specific market segment in the past years relative to competitor's measure.

Based on RBV, Bharadwaj (2000) measured superior performance through four metrics: profit ratio, return on assets and return on sale, the operating income to assets, and operating income to the employee. Radhakrishnan et al,. (2008) measured superior performance through multiple ratio measures: return on assets, return on sales, and return on equity, and relative market share. Their studies find empirical support for IT firms which deliver significantly higher overall firm performance than the industry norms.

Some scholars, critics the metrics use to measure superior performance such as M. deChabert (1998) who suggests that performance metrics must address a measure of performance that is applicable to the industry as well as the variables being investigated. Consequently, he uses cash flow per seat in combination with other academic metrics uses as an index that are grounded on financial performance such as market share and profitability.

Wiggins (1997) suggests that time determines the persistence of superior economics, which may differ from industry to industry depending on some variables such as product life cycle, patent protection, copyrights. It must also be examined through longitudinal study. He uses two economic performance measures that are based on performance indicators, the return on assets and Tobin's q. The superior economic value was operationalized as statically significant average (relative to the industry or reference set).

Many scholars investigated the impact of IT in performance the results are mixed (Mata, 1995, Ray et al, 2004). Most of the results indicate that IT resources are the key enabler of higher order capabilities or interact with other business capabilities to enhance performance, do not enhance firm performance, although they can be considered as the main enabler of performance (Benitez-Amado, and Walczuch, 2012).

Based on the previous discussion, it can be concluded, to measure superior performance it must be compared with the competitors, and the benchmarking firms must be in the same industry. Moreover, all the firms in the industry must be chosen to reduce the potential variability that may appear when choosing 
a single firm as the benchmark for comparison. This process is more useful to prove the outcome of IT capabilities on superior performance as it allows for analysis the industry form different prospective. This also can be utilized to see if the effects can be extrapolated (Benitez-Amado, and Walczuch, 2012).

\section{RBV}

RBV tries to answer the questions about how certain resources can add value to the firm that is how a firm capability can affect cost or performance (Mata al., 1995; Wernerfelt, 2011). Accordingly, to explain how the difference between resources that's available across the firms (even within the same industry) can be source of sustainability of competitive advantage, an internal analysis should be conducted (Barney, 1991; Wernerfelt, 1984).

RBV is considered to be static in nature, thus it may not be proper of testing the behaviour of the firm in a competitive environment (Benitez-Amado and Walczuch, 2012). RBV focuses on firm resources and capabilities in order to highlight the weakness and strength points of the firm (Saqib and Rashid, 2013). Thus, provides the appropriate theoretical lens for examining how factors internal to the firm can be a source of superior performance (Zhang, 2007). Moreover, RBV makes it easy to conduct cross-section research as it facilities, comparing IT resources/capabilities with none IT resources/capabilities. The theory, also can provide a clear connection between IT resource and capability with competitive advantage and firm performance (Wade and Hulland, 2004). Moreover, it offers a utilitarian way to measure the value of IT resource (Melville et al., 2004). Additionally, the RBV has the abilities to differentiate among different IT resource (Wade and Hulland, 2004).

Accordingly, RBV is the most appropriate theory for testing the impacts of IT capabilities on performance.

Many scholars criticized the ways of empirical approach testing RBV to discriminate the impacts of various resource/capabilities in order to find the source of advantage such as the use of large sample and cross-section analysis based on a secondary data, which failed to isolate the source of advantage (e.g., Bowen \&Wiersema, 1999, Rouse and Daellenbach, 1999). Accordingly, they suggest conducting field-based comparisons of accurately selected institutes in order to investigate the source of advantage (Rouse and Daellenbach, 1999). This approach is also criticized as it ignores the value of observed variable (see Levitas \& Chi, 2002; Makadok \& Walker, 2000). Thus, the results will not be verified (Armstrong and Shimizu, 2007).

To solve this problem Armstrong and Shimizu (2007) suggest the use of multiple indicators for measuring resource which can reflect unobserved resource when its compare with one proxy indicators.

\section{Factors That Affect the Relationships between IT Capabilities and Superior Performance}

According to RBV the deviation in firm superior performance is due to the different impacts of resource and capabilities in performance (Ray, Barney, \& Muhanna, 2004). Accordingly, if the independent and dependent variable is controlled by some factor this will overcome the deviation (Henderson \& Cockburn, 1994; Ray et al., 2004). Thereby, a confounding factor may be used when RBV research investigates the relationship between resources \capabilities and performance in the following sequence: first, to have consistency of level between the dependent variable (e. g. Performance) and the focal resources\capabilities). Second, take the effects of industry. Third, the effect of parent effects that is the degree of diversification in the industry. Fourth, the effect of unobserved identity (Armstrong and Shimizu, 2007).

Many factors have an effect on the relationships between IT capabilities and performance. For example, Kettinger et al., (1994) identifies three factors that affect the sustainability of performance, the environmental, macro environment, and the foundation factors. Wade and Hulland (2004) suggest two level 
factors and variables affecting performance the first level is the organizational level, i.e. the level of internal factors, the second level is environmental level. In this level the effects of the industry and macro and organizational factors are interfering i.e. the level of external factors and the interferences between internal and external factors. Melville et al., (2004) suggests three levels of factors and variables that are affecting performance: The organizational factor level, which inhibits in the focal firm; the environmental components which are touched with the genes belong to industry and trade partners, the macro environmental factor level which is concerned with macroeconomic situation.

Organizational factors are the elements or condition that impact the way in which IT is used inside the focal firm (inside the firm) to generate business value (Melville et al., 2004). An example of such factors is: top management commitment (Wade and Hulland, 2004), organization size, geographical position, governance structure, type of industry and the elements that go to build an innovation culture such as continuous improvement (Kettinger et al, 1994).

One of the organizational factors that are not well described by RBV is information intensity which is one of the characteristics of business processes (Hu, and Quan, 2003). The concept of information intensity of the value chain is offered by Porter and Millar (1985) which can be employed to complement the RBV of IT value. Information intensity can be defined as the amount of information necessary in the acquisition, transformation, and delivery of resources for the consumer in final form (Porter and Millar 1985; Glazer, 1993).

Companies with products and services characterized by high information intensity are in a more upright situation to exploit IT-based resources (Porter and Miller 1985; Reich and Benbasat 1996). Accordingly, the probability of using resources to create competitive advantage will increase (Martin, DeHayes, Hoffer and Perkins 1991) or profit will increase. Moreover, when the information intensity in supply chain is high it effected technology diffusion in inter-firm networks (Ranganathan, Teo \& Dhaliwal, 2011). Additionally, IT capability and knowledge capability are more effective in the presence of high environmental uncertainty and information intensity (Mao, Liu, and Zhang, 2014). Thus, can affect the degree in which IT affects performance.

\section{IT Capabilities}

Capabilities are the firm ability to use assets propriety to create and produce and offer its products to a market (Wade and Holland, 2004). There is a need to make a distinction between capabilities that might help the organization achieve competitive advantage and superior performance. This determines the capabilities those are needed for a firm to meet the necessary conditions to compete in a given market (Thompson and Strickland, 2004).

There are different classifications of IT capabilities. The most important classifications are according to the use in the value chain (see, lansiti and Sarnoff, 2006); the IT operational focus (internally or externally) (see Hulland and Wade et al., 2007; Feeny and Willcoks, 1998; Liang, You, and Liu, 2010); their contributions to competitive advantage (see Bi et al., 2010); depending on the tangibility of organizational resources (see Araya et al., 2007); and IT resources classifications (see McAfee, 2006).

However, capabilities classifications differ in its advantages and disadvantages which are discussed by many authors. For example, the internal-external classification is very broad which develops a task oriented classification. This helps the management in explaining which distinctive capabilities deliver unique benefits. On the other hand, this classification does not provide any deeper understanding of the impacts of IT on business processes (see McAfee, 2006), moreover, these IT capabilities have different impact on organizational learning (Cai and Liang, 2010). The classifications that are based on value chain are more detailed and focused on specific technologies and specific organizational processes. Thus, this will give a deeper 
understanding of the impact of IT on business value. On the other hand, this classification is not aimed at facilitating generalizations to other technologies or organizational settings (Illes, 2009). Thus, these advantages and disadvantages make it difficult to decide what the suitable classification of this research is.

One of the problems concerning capability is how to measure capability, which discussed by many authors because it can provide a systematic and theoretical derived a multi-dimensional assessment of a firm's IT capability (Santhanam and Hartono, 2003). Moreover, help to "distangle" the effects from many sources (Armstrong and Katsuhiko Shimizu, 2007). Ray, et al (2004) indicates the metrics that measure superior capabilities should take into consideration the level of capabilities confounding and propose rent. Grant (2001) focus on the ability of capability to produce rent compare to the competitors. Thereby, he suggested efficiency and effectiveness and competitiveness, product quality, flexibility, coordination's, innovations.

In summary, the RBV is the most appropriate theory for testing the impacts of IT capabilities on performance. Moreover, IT classifications that are based on value chain give a deeper understanding of the impact of IT on business value. On the other hand, this classification is not aimed at facilitating generalizations to other technologies or organizational settings. Thus, being the most suitable and comprehensive to measure the impact of its capabilities in performance.

Moreover, it can be concluded in order to investigate the impact of superior performance on IT the firm performance must be benchmarked with competitors in the same industry. This can be used to explore if the effects can be extrapolated. Usually, superior performance is measured in terms of financial and none metrics' that reflects the industry characteristics. In additionally, information intensity as one of organizational factors can affect IT business value which has not been examined well yet.

\section{Research Model and Hypotheses Development}

The research model is drawn from RBV notion that a firm that enjoys superior IT capabilities can create superior performance (Bharadwaj, 2000; Newbert, 2008; Grant, 2010; Denrell, Fang, and Zhao 2013). This model is unlike previous models that tests the relationship between capabilities and superior performance, which is narrowly defined by IT capabilities to fit into a particular context. It takes a comprehensive definition of IT capabilities this has advantages over narrow definition which may inappropriately combine distinct resource/capabilities under a single label, thereby weakening the true relationship validity (Wade and Hulland, 2004). Accordingly, the dependent factor is a superior performance. The independent variable is IT capabilities. The research model contains three components: IT capabilities, superior performance, and information intensity (as a control variable) as shown in the figure I.

This paper focuses on verifying if information intensity is a predictor of superior but not in the direction of the strength of the relation. Thus information intensity is considered as control variables.

According to Wade and Hulland (2004) it is useful to use multiple measures than single ones for measuring superior performance. Accordingly, based on the previous literature, in this study the following metrics are used: the first metrics are profitable, because the managers are more concerned about the return of investment (Porter,1985). To overcome the shortcoming with this metric such as losing large parts of their efficiency in cooperative firms; and the impact of inter-annual sales growth in the sector. A complement metric is used to this metric the growth in sales revenue, because sales growth reflects the conventional measure of profitability and market share (Chow et al, 2008). Moreover, sales growth is of a greater importance in the introductory stage of industry evolution than profitability, because it reflects stimulating customer demand for an embryonic industrial product. Thus, it is the major determinant of the industry's success or failure (Beal, 2003). 


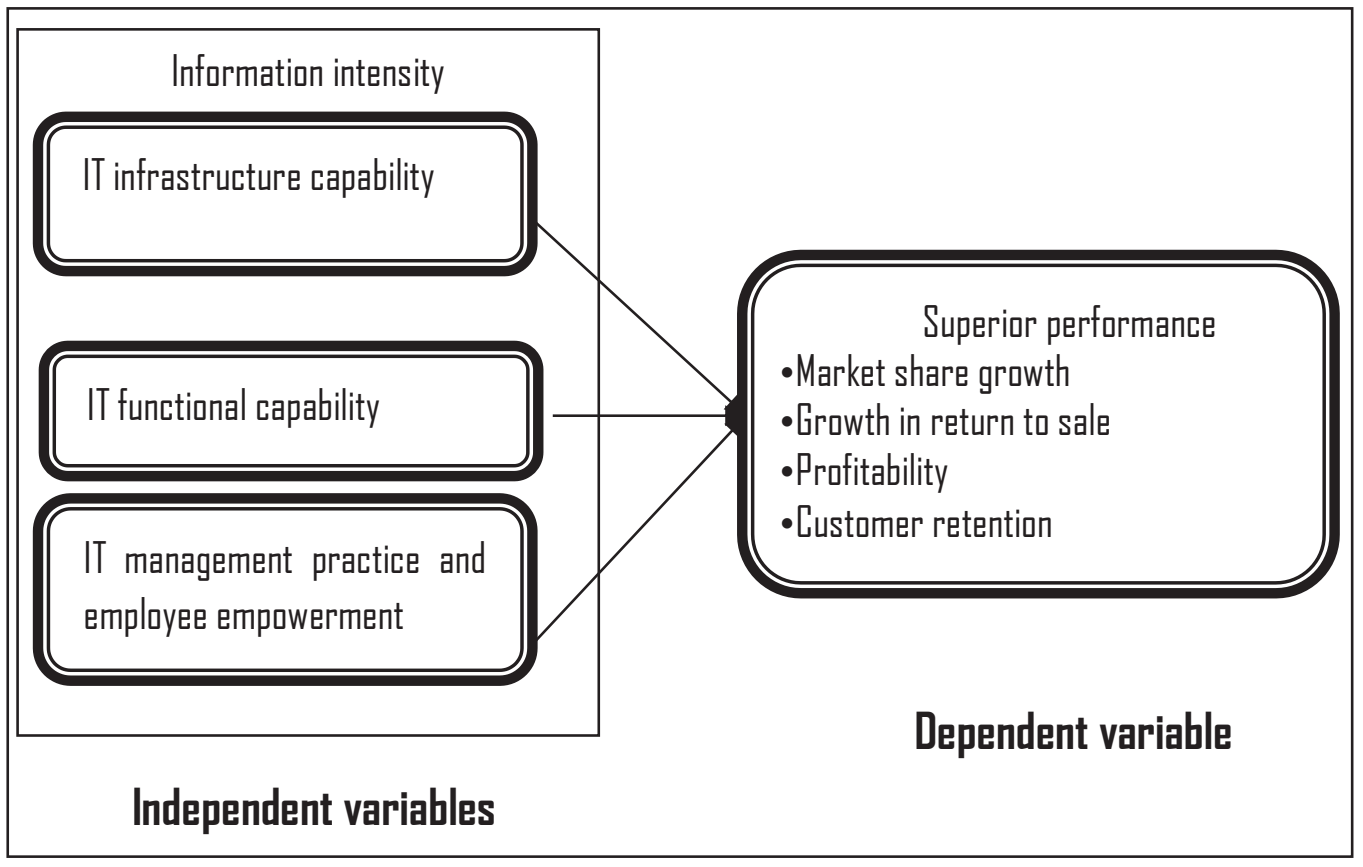

Figure1: Research Model

The third metrics are the market share growth, which reflects the competitive position of the firm in the industry. This metrics if it is set alone is dangerous because some market leaders do not enjoy the best performance and industry structure does not reward leadership (Porter, 1985). Thereby, this metric is complementing the previous metrics.

A complement metrics to previous metrics is the metrics that must take into considerations, industry characteristics as advised by (M. de Chabert, 1998 and Benitez-Amado, and Walczuch, 2012). This study used customer retention because it reflects service industry strategies which emphasizes on creating value to the customer, which is the means by which to align with most profitable customer segments and maximize the value deliver to the (Bingham, 2009). The higher the value delivered to the customer the longest is the retention of a large and loyal customer base for the organization (Panda, 2001).

The IT classifications satisfy the central principles for measuring the implications of IT in firm performance, which is suggested by (Orlikowski and lacono, 2001, Melville et al., 2004). Accordingly, IT capability classifications are chosen through adapting Tallon and Kraemer (2003) of IT business value capabilities at the process level and IT infrastructure flexibility, and lansiti and Sarnoff (2006) classification across the value chain. Another reason to choose this classification is it's closely aligned with business processes across the value chain and IT systems. Accordingly, the total effects of IT could catch up by testing how it can support business functions and core IT capabilities. This makes it easier for decision maker to manage the actual complication of their businesses (lansiti and Sarnoff, 2006).

\section{Hypotheses}

\section{IT Capabilities and Superior Performance}

The literature suggests a positive relationship between IT capabilities and firm performance (e.g. Zhu, 2004; Ravichandran \& Lertwongsatien, 2005; Bharadwaj, 2000). Moreover, IT higher order capabilities can enhance firm performance (Benitez-Amado and Walczuch, 2012). In addition to that Santhanam and Hartono (2003) suggest higher IT capability can generate sustainable superior performance. Accordingly, there is a general association between IT capabilities and superior performance, which can be a foundation of research hypotheses. 


\section{IT Infrastructure Capability and Superior Performance}

Weill and Vitale (2002) define IT infrastructure capability as an integrated set of dependable IT infrastructure services available to support existing applications and new initiatives in firms. The development of efficient IT infrastructure capability which cannot be accumulated by markets will enhance business operation to create sustainable competitive advantage. This IT infrastructure must be established over time (Weill et al., 2002). Accordingly, many authors suggest that IT infrastructure capability affects performance, such as Zhijun and China (2011).

\section{These Statements Suggest:}

$\mathrm{Ha}$ : there is positive relationship between IT infrastructure capability and superior performance.

\section{IT Functional Capability and Superior Performance}

Vorhies \& Morgan (2005) indicate that marketing capability is associated with superior marketing capability. Also, Nath, Nachiappan and Ramanathan (2010) indicate that marketing and operation capability are the key determinant of superior financial performance.

Accordingly:

$\mathrm{Hb}$ : there is positive relationship between IT functional capability and superior performance.

\section{IT Management Practice and Employee Empowerment and Superior Performance}

Strategic capability as one of IT management practice and employee empowerment capability can be defined as the resources and competences of an organization needed for it to survive and prosperity. Parnell (2011) finds that strategy-specific capability can impact superior performance.

Accordingly:

Hc: There is a positive relationship between IT management practice and employee and superior performance

\section{Control Variable}

Control variables are used to account for factors other than the theoretical constructs of interest, which could explain the variance in the dependent variable. In this study the information intensity of the value chain is used as control variables. This is because the firm would be benefits more from investment in IT when there is high information intensity across the value chain. Accordingly, this will improve performance (Hu, and Quan, 2003).

Based on RBV Armstrong and Shimizu (2007) suggest that to provide a more accurate empirical contributions and to maintain consistency of level between the independent variable and the dependent variable at lower level than the firm level. The firm level should be controlled by confounding factors. Accordingly, information intensity will be used as a control variable in this study. On the other hand, in this study, our interest is to verify whether information intensity is predicting of performance or not, but not in not in the direction of the effects. Thus we used it as a control variable not moderator.

\section{Measurement}

This study is cross-section, descriptive, quantitative-correlation-explanatory study. Some questionnaire items were adapted from existing studies. The items are then modified to reflect the applicability within Sudanese context. Table (1) provides a summary of the variables utilized, and supporting literature. All the items in the questionnaire are rated on a five point Likert scale. The list of IT capabilities is adapted from (Iansiti and Sarnoff, 2006) which are divided into IT infrastructures capabilities, employee empowerment and IT functional capabilities.

In order to get more insight about IT capabilities in Sudan banking and insurance sectors, IT capabilities are adapted or modified from different sources. Some items in this typography are deleted because they are not found in Sudanese banking and insurance sectors, according to interview conducted with some IT and middle managers in banking and insurance sectors, besides some IT academic during the phase development of the instruments. 
IT infrastructure capabilities are drawn from the work of Tallon (2007) and Tallon and Kraemer (2003). The dimensions of IT capabilities are connected, compatibility, modularity and skilled IT personnel adaptability (see Tallon, 2007). IT Management Practice and Employee Empowerment Capabilities are drawn from (lansiti and Sarnoff, 2006) which consist from employee empowerment which is IT systems and tools that enable employees to collaborate and use the information required for them to do their jobs. Besides IT management practices which is setting IT priorities, managing IT projects, and using IT as a tool for business innovation. Accordingly, three capabilities are drawn coordination, process planning and support capabilities and IT strategic.

Five capabilities are used to measure IT functional capabilities which consist of IT production and operations, customer relationship and service enhancement capabilities, marketing management capabilities, suppliers' partnership/collaboration and IT financial capabilities.

The superior performance metrics are subjective, which include the following metrics compare with competitors in the five past years: growth in market share, growth in return of sale, profitability, customer retention. This will enable to take some advantage of longitudinal analysis, such as to determine the actual economic and financial trends of performance. Also, it enables to test the competitiveness because the performance is assessed relative to the competitors (Wade and Hulland, 2004). Moreover, this allows analyzing the industry form different prospective, also this can be utilized to see if the effects can be extrapolated (Benitez-Amado, and Walczuch, 2012).

The study uses a subjective performance measure, which can be used (as in our case) when the financial statement data are unavailable, because it allowed comparison among the firms (see Powell and Dent-Micallef, 1997; Tippins and Sohi, 2003). Moreover, there are high correlations between objective and subjective measures thus the results would not be affected (Kumar et al., 2011; Song et al., 2005).

Information intensity is defined as the significance of the information component in value chain activities and is demonstrated by the level of accuracy, frequency of updates, and the magnitude and extent of information employed in operations (Teo \& King, 1997). The items of information intensity are adapted from Kearns \& Lederer (2001).

Table (1): Summary of the Variables Utilized and Supporting Literature

\begin{tabular}{|c|c|c|}
\hline \multicolumn{3}{|c|}{ Superior Performance } \\
\hline Dimension & \multicolumn{2}{|l|}{ Support Reference } \\
\hline Market share growth & \multicolumn{2}{|l|}{ (Day \& Wesley, 1988) } \\
\hline Growth on return to sale & \multicolumn{2}{|l|}{ Radhakrishnan et al (2008) Bharadwaj (2000) } \\
\hline Profitability & \multicolumn{2}{|l|}{ Day, Van den Bulte (2002) Salter and Narver (1994) Woodruff (1997) } \\
\hline Customer retention & \multicolumn{2}{|l|}{ Day, Van den Bulte (2002) Salter and Narver (1994) (Day \& Wesley, 1988). } \\
\hline Information intensity & \multicolumn{2}{|l|}{ Kearns \& Lederer (2001) } \\
\hline \multicolumn{3}{|c|}{ IT Capabilities } \\
\hline Dimension & Definition & Support Reference \\
\hline IT infrastructure & $\begin{array}{l}\text { It is the foundational elements that provide secure, reliable con- } \\
\text { nectivity to information inside and outside a company which in- } \\
\text { cludes: Connectivity and modularity of software, Compatibility } \\
\text { integration capabilities) and adaptability (IT human skill). }\end{array}$ & $\begin{array}{ll}\text { Tallon } & \text { and } \text { Kraemer } \\
(2003), & \text { Tallon } \quad(2007)\end{array}$ \\
\hline $\begin{array}{l}\text { IT management practice \& } \\
\text { employee empowerment }\end{array}$ & $\begin{array}{l}\text { Includes: IT strategic capability, IT planning capability, IT coordina- } \\
\text { tion capability. }\end{array}$ & $\begin{array}{l}\text { Zhang (2005); Talon (2007); } \\
\text { Kearns \& Lederer (2001) }\end{array}$ \\
\hline IT functional capabilities & $\begin{array}{l}\text { Includes: IT production capability, customer relationship and ser- } \\
\text { vice enhancement capabilities, marketing capabilities, supplier's } \\
\text { partnership/collaboration, and IT financial capabilities. }\end{array}$ & $\begin{array}{l}\text { Zhang(2005); Tallon \& Krae- } \\
\text { mer (2003), Kearns \& Leder- } \\
\text { er (2001), Tallon (2007) }\end{array}$ \\
\hline
\end{tabular}




\section{Data Collection and Research Instrument}

The data are collected by questionnaire. Part of the survey is multiple choices, and the rest is designed on a five Likert scale. After discussions with some senior managers in the banking and insurance sector, it is concluded that the data could not be gathered through one questionnaire. Whilst IT senior staff were not able to assess the performance, at the same time functional managers were not able to assess IT performance. Accordingly, the questionnaire is divided into two forms, one for IT senior staff and the other for functional managers. The first deals with superior performance and information intensity. The second is about IT capabilities.

\section{Population and Sampling and Unit of Analysis}

The study is focused on Sudanese banking and insurance sectors. The above services are chosen because these sectors are both large and medium size organizations and a successful company may pay attention to the benefits of information systems (Spanos and Lioukas, 2001). The population of this study is banking and insurance institutions that have worked for more than five years, because these institutions have the ability to evaluate their IT resources and capabilities more than the others. Moreover, can evaluate whether they gain superior performance or not compare to competitors.

As a superior performance is assessing through benchmarking the firm performance relative to the competitors in the five past years. Thus, the whole industry is chosen as population. This will lead to get better results and achieve an acceptable level of generalization and to reduce the potential variability that may appear when chooses a single firm as the benchmarking for comparison. Moreover, this process allows analysis the industry from a different prospective. This also can be utilized to see if the effects can be extrapolated (Benitez-Amado, and Walczuch, 2012).

The unit of observation for the first questionnaire is the middle manager at the headquarters in each department that related to customers, who had worked for several years in the organization. Thus, they have the capability to assess superior performance. A single respondent is used in each business unit, because only one or two members of the top management team had a complete picture in each department. Accordingly, a total number of 143 questionnaires are distributed to $90 \%$ of the total targeted institutions. The sample has the following characteristics: (1)77.7\% of the banking sector; (b) the average age of the respondents is 41.43 years; (c) $66.4 \%$ are male. More than $78.4 \%$ are graduated or postgraduate.

The unit of observation for the second questionnaire is IT senior staff members at the headquarters who can evaluate the effects of IT on performance. A single respondent is used in each business unit, because only one or two members of the top management team had a complete picture in each department. Accordingly, a total number of 83 questionnaires are distributed to $84 \%$ of the total targeted institutions. The sample has the following characteristics: (1)77.7\% of the banking sector; (b) the average age of the respondents is 36.5 years; (c) $83.4 \%$ male and more than $92 \%$ are graduated or postgraduate. The unit of analysis for this study is the institute.

\section{Analysis and Results}

Factor analysis is conducted in order to identify the underlying dimension scale of IT capabilities and superior performance and information intensity and also to reduce the number of dimensions into smaller sets of factors, thereby allowing the formation and refinement of the theory. Moreover, the purpose of factor analysis is to make sure each dimension of IT capabilities are on unit which suggested by Maçada, Beltrame, Mateus, Dolci, Becker and João (2012).

Since this paper conceptualized IT capabilities consisting of three types, factor analysis was done for every type separately. In addition, separate factor analysis helps to test for construct convergence with maximally similar sets of variable as well as to avoid violating recommended minimal sample size to parameter estimate ratios suggested by Kerlinger (1986). This statistical rule of thumb has also been used in previous studies of testing capability such Baker and Sinkula (1999), and Bardhan et al. (2007). 
Table (2) shows the results of factor analysis of seven items of IT infrastructure capability which reveals that only five items will explain IT infrastructure capability. Cronbach's Alpha for IT infrastructure capability is 0.770.

Table (2): Factor Analysis of IT Infrastructure Capability

\begin{tabular}{lc}
\multicolumn{1}{c}{ Items } & Factor Loading \\
\hline Our systems are sufficiently flexible to link with external parties. & $\mathbf{0 . 8 1 6}$ \\
\hline Institution databases are accessed through many different protocols. & $\mathbf{0 . 6 8 3}$ \\
\hline Legacy systems within our institution do not hamper the development of new IT applications & $\mathbf{0 . 7 3 4}$ \\
\hline Software applications can be easily transported and used across multiple platforms. & $\mathbf{0 . 6 7 3}$ \\
\hline Our IT personnel have the ability to understand the priorities and objectives of the organization & $\mathbf{0 . 6 5 3}$ \\
\hline Eigen values & 3.028 \\
\hline Percentage of Variance Explain & 43.6 \\
\hline
\end{tabular}

Table 3 shows the results of the factor analysis of IT management practice and employee empowerment. The results of the analysis indicate that only three factors will explain IT capability. The first one includes two items of strategic planning capabilities and one item from strategic capabilities all of which indicate to improve performance. Accordingly, it termed as improvement capabilities. The second factor contains two constructs of strategic capability therefore it termed as IT strategic capability. Cronbach's Alpha for the first factor is $\alpha=0.657$ and for the second factor is 0.740 .

Table (3): Factor Analysis of IT Management Practice and Employee Empowerment

\begin{tabular}{lcc}
\hline Items & Factor Loading \\
\hline & 1 & 2 \\
\hline IT improves managerial decision-making. & $\mathbf{0 . 6 9 2}$ & 0.160 \\
\hline IT provides the institutional advantages such as lower costs or product differentiation. & $\mathbf{0 . 7 9 1}$ & -.051 \\
\hline IT enhances the effectiveness of our overall performance. & $\mathbf{0 . 6 6 0}$ & 0.085 \\
\hline IT creates barriers to keep competitors from entering our market. & 0.139 & $\mathbf{0 . 8 6 0}$ \\
\hline IT influences the buyer's decision to switch to service. & 0.041 & $\mathbf{0 . 8 4 4}$ \\
\hline Eigen values & 3.390 & 1.342 \\
\hline Percentage of Variance Explain & 37.664 & 52.576 \\
\hline
\end{tabular}

Table (4) shows the results of factor analysis of IT functional capabilities. The outcomes propose that IT functional capability can be interrupted as: first: factor one includes some items of IT production capability, financial capacity. Consequently, the first element is labelled as IT internal function capability. Second: factor two contains some constructs of IT customer relationship and service enhancement capabilities, and IT marketing capability. Thereby this factor is termed as IT external function capability. Factor three which contains one item is deleted as recommended by Hinkin (1998). Cronbach's Alpha for the first factor is 0.887 and for the second factor 0.850 .

Table (4): Factor Analysis of IT Functional Capabilities

\begin{tabular}{lccc}
\hline \multicolumn{1}{c}{ Items } & \multicolumn{2}{c}{ Factor Loading } \\
\hline & 1 & 2 & 3 \\
\hline IT allows economies of scale for the service. & 0.401 & 0.266 & $\mathbf{0 . 6 8 7}$ \\
\hline IT improves the quality of service. & 0.273 & $\mathbf{0 . 7 1 2}$ & 0.195 \\
\hline IT increases the number of clients who can be served per employee. & 0.402 & $\mathbf{0 . 6 7 0}$ & -0.078 \\
\hline IT improves the institution's capability to reach clients at different geographic locations. & $\mathbf{0 . 6 6 5}$ & 0.394 & -0.117 \\
\hline $\begin{array}{l}\text { IT enhances the capabilities of the institution to respond to the needs of } \\
\text { different clients differently. }\end{array}$ & $\mathbf{0 . 6 5 2}$ & 0.382 & 0.106 \\
\hline IT helps track market response to pricing strategies. & $\mathbf{0 . 6 6 2}$ & 0.112 & 0.167 \\
\hline IT enables sales people to increase sales per client. & $\mathbf{0 . 9 0 4}$ & 0.023 & 0.078 \\
\hline IT improves accuracy of sales forecasts. & $\mathbf{0 . 8 8 9}$ & 0.189 & 0.091 \\
\hline IT helps track market response to advertising campaigns. & $\mathbf{0 . 7 2 3}$ & 0.183 & 0.159 \\
\hline
\end{tabular}




\begin{tabular}{lccc}
\hline \multicolumn{1}{c}{ Items } & \multicolumn{2}{c}{ Factor Loading } \\
\hline & 1 & 2 & 3 \\
\hline IT helps the institution get better services from their suppliers $\backslash$ partnership. & $\mathbf{0 . 6 6 2}$ & 0.008 & 0.416 \\
\hline IT reduces the required time to prepare financial reports. & 0.175 & $\mathbf{0 . 8 3 5}$ & 0.217 \\
\hline IT helps your institution to prepare different special financial reports. & 0.079 & $\mathbf{0 . 9 1 8}$ & 0.137 \\
\hline IT helps reduce the costs of preparing financial reports. & 0.044 & $\mathbf{0 . 7 9 9}$ & 0.166 \\
\hline Eigenvalues & 6.657 & 2.238 & 1.115 \\
\hline Percentage of Variance Explain & 44.378 & 14.922 & 7.432 \\
\hline
\end{tabular}

Table 5 shows the factor analysis of four items of superior performance. The outcomes show that the dimensions of superior financial are valid. Cronbach's Alpha score is 0.887 .

Table (5): Factor Analysis of Financial Performance

\begin{tabular}{lcc}
\hline & Item & Factor Loading \\
\hline Market share growth & .848 \\
\hline Growth in sales revenue. & .942 \\
\hline Organization profitability. & .855 \\
\hline Customer retention. & .782 \\
\hline
\end{tabular}

Table 6 shows that results of factor analysis of information intensity the results yield a clear indication of unidimensionality of this factor as factor loading is above 0.6 as suggested by (Hair et al., 2006). Cronbach's Alpha score 0.849

Table (6): Factor Analysis of Information Intensity

\begin{tabular}{lc}
\hline \multicolumn{1}{c}{ Item } & Factor Loading \\
\hline Information is used to a great extent in our production or service operations. & .873 \\
\hline Information used in our production or service operations is frequently updated. & .874 \\
\hline Information used in our production or service operations is usually accurate. & .814 \\
\hline Many steps in our production or service operations require frequent use of information & .757 \\
\hline
\end{tabular}

Note that Cronbach's Alpha score of all dimensions is above or approaching 0.60 . Accordingly, we are able to meet Nunnally's (1978) guideline that modest reliability in the range of 0.50 to 0.60 will be sufficient for exploratory research.

\section{Correlation Analysis}

The purpose of this analysis is to investigate the relationship between variables for the primary testing hypotheses. Another use of this correlation matrix is to investigate the presence of multicollinearity. The figure below shows the result of correlation analysis of the all variables. According to the result of correlation matrixes shown above no correlation is near 1 (or approaching .8 or .9). This reveals that multicollinearity is not a significant problem in this particular data set.

Table (7): Correlation analysis

\begin{tabular}{|c|c|c|c|c|c|c|c|}
\hline & $\begin{array}{c}\text { Superior } \\
\text { Performance }\end{array}$ & $\begin{array}{l}\text { Information } \\
\text { Intensity }\end{array}$ & $\begin{array}{c}\text { IT Infra- } \\
\text { structure } \\
\text { Capability }\end{array}$ & $\begin{array}{c}\text { Internal } \\
\text { Functional } \\
\text { Capability }\end{array}$ & $\begin{array}{c}\text { External } \\
\text { Functional } \\
\text { Capability }\end{array}$ & $\begin{array}{c}\text { IT } \\
\text { Strategic } \\
\text { Capability }\end{array}$ & $\begin{array}{c}\text { IT } \\
\text { Performance } \\
\text { Capability }\end{array}$ \\
\hline Superior performance & 1.000 & & & & & & \\
\hline information intensity & .493 & 1.000 & & & & & \\
\hline IT infrastructure capability & $-.057-$ & .039- & 1.000 & & & & \\
\hline Internal functional capability & $-.246-$ & $-.118-$ & .212 & 1.000 & & & \\
\hline External functional capability & -.029 & $-.100-$ & .725 & .244 & 1.000 & & \\
\hline IT strategic capability & .031 & .010 & .540 & .068 & .573 & 1.000 & \\
\hline IT performance capability & $-.213-$ & $-.221-$ & .287 & .651 & .385 & .010 & 1.000 \\
\hline
\end{tabular}


Also the correlation analysis gives indication about the association between variants, but not determined whether it is direct or indirect relations. Thus a hierarchical regression will be conducted to investigate that.

\section{Hypotheses Testing}

A regression analysis is conducted for each construct of IT capability as independent variable and superior performance as dependent factor. IT capability is controlled by information intensity.

\section{Regression Analysis of IT Functional Capability and Superior Performance}

Table 7 shows the results of regression analysis, among IT internal and external function and superior performance.

Table (8): Regression of IT functional capabilities and superior performance

\begin{tabular}{lll}
\hline \multicolumn{1}{c}{ Independent Variables } & \multicolumn{1}{c}{ Dependent Variables } \\
\hline Control Variable & Step 1, Standardized Coefficients Beta & Step 2, Standardized Coefficients Beta \\
\hline Information intensity & $.475^{* *}$ & \\
\hline Model variable & & $.424^{* *}$ \\
\hline \multicolumn{1}{l}{ IT external functionality } & \\
\hline IT internal functionality & & $.262^{*}$ \\
\hline F value & $10.185^{* *}$ & -.087 \\
\hline $\mathrm{R}^{2}$ & .225 & $1.452^{* *}$ \\
\hline Adjusted $\mathrm{R}^{2}$ & .203 & .288 \\
\hline F change & $1.452^{*}$ & .223 \\
\hline
\end{tabular}

Note: Level of significance: ${ }^{*} \mathrm{p}<0.10,{ }^{* *} \mathrm{p}<0.05,{ }^{* * *} \mathrm{p}<0.01$

The results of this two-step regression indicate that the two models are significant $((F=10.185, p<0.05$; $\mathrm{F}=1.452, \mathrm{p}<0.05)$. In the first step, the control variable has a significant effect on IT functional capabilities. The control variable explains $20 \%$ of variation in the first step while adding IT functional capabilities, explains $22 \%$ of the variation in superior performance. This implies that control variable and IT functional capabilities explain $42 \%$ of the variation in superior performance. The outcomes indicate that only IT external function has an effect on superior performance $(B=0.262, p<0.1)$.

\section{Regression Analysis of IT Management Practice and Employee Empowerment and Superior Performance}

The effects of the two step regression analysis, among IT performance and strategic capabilities and superior performance is presented in table 8. The two items of IT Management Practice and Employee Empowerment are controlled by information intensity.

Table (9): Regression of IT Management Practice and Employee Empowerment and Superior Performance

\begin{tabular}{lll}
\hline Independent Variables & \multicolumn{1}{c}{ Dependent Variables } \\
\hline & Step 1, Standardized Coefficients Beta & Step 2, Standardized Coefficients Beta \\
\hline Control variable & & \\
\hline Information intensity & $.475^{* *}$ & $.485^{* *}$ \\
\hline Model variable & & .076 \\
\hline IT performance capability & & -.018 \\
\hline IT strategic capability & & $3.311^{*}$ \\
\hline F value & $10.185^{* *}$ & .231 \\
\hline $\mathrm{R}^{2}$ & .225 & 162 \\
\hline Adjusted R & .203 & $3.311^{*}$ \\
\hline F change & $10.185^{* *}$ & \\
\hline
\end{tabular}

Note: Level of Significance: ${ }^{*} p<0.10,{ }^{* *} p<0.05,{ }^{* * *} p<0.01$ 
The results suggest that the two models are significant $(F=10.185, p<0.05 ; F=3.311, p<0.05)$. The control variable has significant effects on both points of IT strategic capability and employee empowerment. The control variable explains $22 \%$ of variation in superior performance. IT Management Practice and Employee Empowerment explain $23 \%$ of variation in superior performance. Accordingly, both information intensity IT strategic capability and employee empowerment explain $45 \%$ of variation in superior performance. The results also indicate that both items of IT strategic capabilities and employee empowerment have no significant effects on superior performance.

\section{Regression Analysis of IT Infrastructure and Superior Performance}

Table 9 explores the results of two step regression analysis between IT infrastructure capabilities and superior performance which is controlled by information intensity.

Table (10): Regression of IT Infrastructure and Superior Performance

\begin{tabular}{lll}
\hline Independent Variables & \multicolumn{1}{c}{ Dependent Variables } \\
\hline & Step 1 Standardized Coefficients Beta & Step 2 Standardized Coefficients Beta \\
\hline Control variable & $.475^{* * *}$ & $.418^{* *}$ \\
\hline Information intensity & \\
\hline Model variable & $.161^{*}$ \\
\hline IT infrastructure & $5.609^{*}$ \\
\hline F value & $10.185^{* * *}$ & .248 \\
\hline $\mathrm{R}^{2}$ & .225 & .204 \\
\hline Adjusted $\mathrm{R}^{2}$ & .203 & $5.609^{*}$ \\
\hline F change & $10.185^{* * *}$ &
\end{tabular}

Note: Level of significance: ${ }^{*} \mathrm{p}<0.10,{ }^{* *} \mathrm{p}<0.05,{ }^{* * *} \mathrm{p}<0.01$

The results indicate that the two models are significant $((F=10.185, p<0.05 ; F=5.609), p<0.05)$. The control variable has significant effects on IT infrastructure capability. The control variable explains $22 \%$ of variation in superior performance. IT infrastructure capability explains $24 \%$ of variation in superior performance. Both IT infrastructure capability and information intensity explain $46 \%$ of variation in superior performance. Moreover, the results show that IT infrastructure capabilities have significant effects on superior performance $(ß=.161, p<0.1)$.

\section{Discussion}

The aim of this study is to investigate how IT capabilities affect superior performance. The outcomes of the analysis show that IT external functional capabilities do affect superior performance. This confirms with Dutta et al. (1999) as they consider marketing capabilities (as one of the external capabilities) can create a superiority among other firms. Also, consist with Coltmanet al. (2011) and ElKordy (2014) who suggests that customer relation management capability (as one of the external capabilities) has an effect on performance. Moreover, the finding of this study is confirmed by Liang, You, and Liu (2010) who indicated that IT external capabilities have effects on financial performance. This may be due to the nature of IT that cannot directly generate finical performance without integrated with other business functions such as marketing and supply chain management (Liang, You, and Liu, 2010).

Moreover, the results suggest that IT infrastructure capabilities do effects superior performance when controlled by information intensity. This confirms with (Bharadwaj, 2000, and Santhanam and Hartono, 2003) as they suggest that IT infrastructure capability can generate rent. IT Management Practice and Employee Empowerment capabilities have no effects on superior performance. This is not confirmed by Antonia Gil-Padilla and Toma's Espino-Rodri'guez (2008) as they suggest the strategic value (as one of the IT Management Practice and Employee Empowerment) has effects on performance. This may be due to the high cost required to install strategic applications (Turban, 2004). 
The results of the study, however, support the inclusion of information intensity as control variables, since this variable is predictors of superior performance. This implies that firm that is predicted as information intensity user can benefit more from IT to achieve superior performance. This finding consists with Ravichandran and Lertwongsatien (2002) and Martin, DeHayes, Hoffer and Perkins (1991) who indicate that the probability of a company to use IT to gain competitive advantage will increase if there is intensive usage of information across the value chain.

Based on the study results it can be concluded that, the results increase theoretical and empirical understanding of how IT capabilities affect superior performance through comprehensive model of IT capabilities. The finding indicates that only IT external capabilities and IT infrastructure capability have an effect on superior performance. Moreover, information intensity as organization factor can be considered as a predictor of the effects of IT capabilities on performance.

The results of the study can be considered as extension of other business value of IT that based on RBV studies such as (Wade and Hulland, 2004; Liang, You, and Liu, 2010; Ravichandran \& Lertwongsatien, 2005; Melville et al., 2004; Armstrong and Shimizu,2007). This because it solves some empirical issue of testing RBV such as using a comprehensive model of IT and narrow definition of IT capabilities, thereby able to distangle the source of advantage as suggested by Wade and Hulland (2004). Moreover, the results of the study indicate the impact of information intensity as an organizational factor thus give some boundaries of RBV, which are a central part of a good theory as suggested by Bacharach (1989). This gives a need for future research to show if information system intensity is a mediator or moderator factor and investigate other organizational factors. Moreover, the study investigates the source of the deviation of superior performance due to the different impacts of resource and capabilities in performance at the firm as suggested by Ray, Barney, \& Muhammad (2004). Accordingly, the independent and dependent variable is controlled by information intensity this will overcome the deviation as suggested by Henderson \& Cockburn (1994); Ray et al., (2004); Armstrong and Shimizu, (2007).

This study tests IT capability across industries with varying information intensity. Thus, providing an understanding of how key IT capabilities affect the competitiveness of these sectors differently as suggested by Yin and Yang (2011). Additionally, the study used field-based comparisons of accurately selected institutes in order to investigate the source of advantage of superior performance as suggested by Rouse and Daellenbach (1999). This enables to isolate the source of advantage. Moreover, the study differentiates between IT resource and capability, thus make a clear distinction between the capacity building mechanisms (capabilities at different levels), acquiring and possessing mechanism (which includes resources and capabilities) versus the processes of deploying that capacity, to show how RBV sustains competitive advantage or performance as suggested by Kraaijenbrink and Spender and Aard (2009).

\section{Implications}

The fundamental managerial implications of the study are that IT infrastructure capabilities and IT external capabilities are important capabilities that enables superior performance and should be recognized by the managers. The study offers a detailed framework for measuring the level of IT capabilities across the value chain. This offers a tool for the Sudanese decision makers in insurances and banking to evaluate IT capabilities in order to enable them prioritize among their companies' gaps in IT capability compared to competitors, as well as assessment of the impact of those gaps on superior performance in the presence of any organizational factors such as information intensity. Thus, they can create a plan that generates a greater return on IT investment form IT capabilities across the value chain that affected by information intensity more than others because the value chain with high information intensity would benefit most from investments in IT (Hu, and Quan, 2003). 
From academic point of view, this study helps to establish a new framework of analysis by introducing a comprehensive model of analysis for the study of the IT capabilities that is based on the RBV. This serves as a support in contemplating a perspective of internal analysis of the firm in the presence of some organizational factors (information intensity). This can help identify the IT capabilities that may be specified in its action according to the contribution to firm performance. The study also, contributes to the RBV to verify the theoretical tenets of RBV logic that IT capabilities produce different performance results depending on the complex process in which a firm integrates the accumulative effects in the presence of some organizational factors such as information intensity.

The narrow definitions of IT capabilities help to fine-tune the understanding of "capability e-specificity" and its impact on performance in a given setting. On the other hand, the danger of capabilities that is overly narrow may lead to difficulty in generalizations to new contexts and potential implications might become lengthy for practical research use (Zhenyu, 2011).

The study also, permits an empirical demonstration of theoretical approach that was previously untested in the Sudanese banking and insurance sector. Although, there are some implication of the research model and its implantation, this study has some limitations that must be taken into consideration in future research. These limitations are high lightened in the following section:

There should be an analysis of other factors that impact the relationship between IT capabilities and organizational performance.

The use of cross-sectional approach represents a limitation on the explanation of the results because it does not provide evidence for cause and effect relationship unlike the longitudinal research design (ElKordy, 2014) as suggested by Wiggins (1997). This will help decision makers get full view about how IT capabilities effects superior performance in a long period of time and thus design the strategic plan

Another limitation of this study is that it does not compare capabilities and superior performance across the two sectors (insurance and banking sector). Testing of capabilities across industries with varying information intensity can provide a new understanding of how IT capabilities affect the competitiveness of these sectors differently (Bhatt and Grover, 2005).

This study does not take into consideration the effect of the firm size which may affect the way it generates its IT capabilities as shown in the previous study. These aspects are recommended for future research direction. 


\section{Refrences}

- Araya, S., Chaparo, J., Orero, A., \& Joglar, H. (2007). "An integrative view of IT and organizational resources and capabilities", Informing Science and Information Technology, Vol. 4, 629-639.

- Armstong, C. E. \& Shimizu, K. (2007). "A review of approaches to empirical research on the resource-based view of the firm", Journal of Management, 33 (6), 959-85.

- Bacharach, S. B. (1989). “Organizational theories: Some criteria for evaluation”, Academy of Management Review14: 496 -515.

- Baker, W. E., and J. M. Sinkula. (1999). “The Synergistic Effect of Market Orientation and Learning Orientation on Organizational Performance," Journal of the Academy of Marketing Science, 27, 411-427.

- Barney, J. B. (1991). "Firm resources and sustained competitive advantage", Journal of Management, 17, 99-120.

- Barney, J. B. (2002). Gaining and Sustaining Competitive Advantage. London. Prentice Hall.

- Beal, R. M. ( 2001.) Competitive Advantage: Sustainable or Temporary in Today's Dynamic Environment?. Tallahassee, Florida: School of Business and Industry. Florida A \& M University.

- Benitez-Amado, J. and Walczuch, R. M. (2012). “Information technology, the organizational capability of proactive corporate environmental strategy and firm performance: A resource- based analysis", European Journal of Information Systems 21 (6), 664-679.

- Bharadwaj, A. (2000). "A resource-based perspective on information, technology capability and firm performance: an empirical investigation", MIS Quarterly, 24 (1), 169-196.

- Bhatt, D. and Grover, V. (2005). "Types of Information Technology Capabilities and Their Role in Competitive Advantage: An Empirical Study", Journal of Management Information Systems, 22(2) , 253 - 278, http://www.jmis-web.org.

- Bi, R., Smyrnios, K. X., and Kam, B. (2010). "Information System Capabilities as a Driving Force in Enhancing Organizational Performance: An Empirical Study", 14th Pacific Asia Conference on Information Systems (PACIS). Taipei, Taiwan

- Bowen, H. P., \& Wiersema, M. F. (1999). “Matching method to paradigm in strategy research: Limitations of cross sectional analysis and some methodological alternatives", Strategic Management Journal, 20: 625-636.

- Byrd, T. and Byrd. W. (2010). “Contrasting IT Capability and Organizational Types: Implications for Firm Performance". Journal of Organizational and End User Computing (JOEUC), 22 (4), 1-23.

- Cai Z., Liang L. (2010) "Effects of IT Capability and External Integration On Organizational Responsiveness: an Organizational Learning Perspective" Asia Conference on Information System PACIS 2014 Proceedings.

- Chen Y. Wang Y. Nevo S. Jin J. Wang L. and Chow S. (2014). "IT capability and organizational performance: the roles of business process agility and environmental factors « European Journal of Information Systems, 23 (3), 326-342.

- Chow, W.S., Madu, C.N., Kuei, C.H., Lu, M.H., Lin, C. and Tseng, H. (2008). “Supply chain management in the US and Taiwan: An empirical study", OMEGA, 36 (5), 665-679.

- Coltman, T., Devinney, T.M. and Midgley, D. (2011). “Customer relationship management and firm performance", Journal of Information Technology, 26 (3) , 205-219.

- Crook, T.R., Ketchen, D.J., David, J., Combs, J.G. and Todd, S.Y. (2008), "Strategic resources and performance: a meta-analysis", Strategic Management Journal, Vol. 29 No. 11, pp. 1141-54. 
- Day, G., \& Van der Bulte, C. (2002). “Superiority in customer relationship management: Consequences for competitive advantage and performance", The Wharton School, Retrieved from the World Wide Web August 2004: http://wwwmarketing.wharton.upenn.edu/ideas/pdf/Van\%20 den\%20Bulte/Superiority\%20in\%20Customer\%20Relationship\%20Management.pdf

- Denrell, J., Fang, C., Zhao, Z., (2013). "Inferring superior capabilities from sustained superior performance: A Bayesian analysis", Strategic Management Journal, 34(2), 182-196.

- Dutta, S., Narasimhan, O., \& Rajiv, S. (1999). "Success in high-technology markets: Is marketing capability critical?", Marketing Science 18 (4), 547-568.

- Elkordy, M. (2014), The Impact of CRM Capability Dimensions On Organizational Performance", European Journal of Business and Social Sciences, 10 (2), 128-146

- Elkordy, M. (2014). The Impact of CRM Capability Dimension on Organizational Performance. European Journal of Business and Social Sciences, 10(2),128-146

- Feeny, D. and Willcocks, L. (1998). "Core IS Capabilities for Exploiting Information Technology", Sloan Management Review, 39 (3) , 9-21.

- Glazer, R. (1993). "Measuring the Value of Information: the information-intensive organization", BM Systems Journal, 32 (1) , 99-110

- Grant, R. M. (2005). Analyzing Resources and Capabilities: Contemporary Strategy Analysis. Blackwell Publishing.

- Grant. R. B. (1999). "A resource based theory of competitive advantage: Implications for strategy formulation", California Management Review, 33 (3), 114-135.

- Grant M. (1991). "The Resource-Based Theory of Competitive Advantage Implications for Strategy Formulation", Strategic Management Journal33 (3), 119-135.

- Grant R.M. (2010). Contemporary strategy analysis. Oxford: John Wiley and Sons

- Hanningtone, J. G., Struwig, M. and Smith E. E (2013). "Creating a sustainable competitive advantage at a high performing firm in Kenya", African Journal of Business Management, Vol. 7(21), pp. 2049-2058

- Henderson, R. M. and I. Cockburn. (1994). “Measuring competence? Exploring firm effects in pharmaceutical research", Strategic Management Journal, Summer Special Issue, 15, 63-84.

- Hinkin, T. R. (1985). “Development and application of new social power measures in superior subordinate relationships", Unpublished doctoral dissertation, University of Florida.

- Hinkin, T. R. (1998). "A brief tutorial on the development of measures for use in survey questionnaires", Organizational Research Methods, 1, 104-121.

- Hu, Q. and Quan, J.( 2003). “Information Intensity and the Impact of IT Investments on Productivity: An Industry Level Perspective", Proceedings of the 11th European Conference on Information Systems, June19-21, Naples, Italy.

- Iansiti, M.; Sarnoff, D. (2006). "Enterprise IT Capabilities and Business Performance”, Keystone Strategy, inc. download.microsoft.com/.../Development. Whitepaper. Keystones rate.

- Illes, F. (2009). "New Firm-level Information Technology Classification Model and the Effect on Firm Performance: Theory Building \& Empirical Analysis", Master's thesis, (MoT) program at the Technical University of Delft (TU Delft)

- Jones G, Hill C. (2004). Strategic Management: An Integrated Approach. Houghton Mifflin: Boston.

- Kearns, G. S. \& Lederer, A. L. (2003). "A resource-based view of strategic IT alignment: How knowledge sharing creates competitive advantage", Decision Sciences, 34 (1), 1-29. 
- Keramati, A. (2007). "Assessing the Effects of Information Technology on firms Performance using Canonical Correlation Analysis: A survey of Iran Car parts suppliers Sector« Proceedings of World Academy of Science, Engineering and Technology, Volume 21, May 2007.

- Kerlinger, F. N. (1986). Foundations of behavioural research. (3rd ed.). San Diego, CA: Harcourt

- Kettinger, W., Grover, V., Guha, H. and Segars, A. (1994). "Strategic Information Systems Revisited: A Study in Sustainability and Performance" MIS Quarterly, 18, (1), 31-38.

- Kraaijenbrink J., Spender J.C., and Aard J. G. (2010). "The Resource-Based View: A Review and Assessment of Its Critiques, "Journal of Management, 36 (1), 349-372.

- Levitas, E. \& Chi, T. (2002). “Rethinking Rouse and Daellenbach's rethinking: isolating vs. testing for sources of sustainable competitive advantage" Strategic Management Journal, 23 (10), 957-962.

- Liang, T.P., You, J.J., and Liu, C.C.(2010). "A resource-based perspective on information technology and firm performance: a meta-analysis," Industrial Management \& Data Systems, (110: 8), 2010, 1138-1158. 27.

- $\quad$ Liang, T. P., You, J. J., and Liu, C. C. (2010) "A resource-based perspective on information technology and firm performance: a meta-analysis," Industrial Management \& Data Systems, pp.110:8), 2010, 1138-1158.

- Lu Y. and Ramamurthy K. (2011). “Understanding the link between information technology capability and organizational agility: an empirical examination" MIS Quarterly, 35 (4), 931-954.

- MA, H. (1999). "Anatomy of Competitive Advantage: a SELECT Framework", Management Decision, 37 (9), 709-718.

- Makadok R.; Walker G. (2000). "Identifying a distinctive competence: forecasting ability in the money fund industry" Strategic Management Journal, 21 (8), 853-864

- Makau, S. M., Wawire, N. W., \& Ofafa, G. A. (2013). "An Empirical Study on the Relationship between Organizational Factors and Adoption of ICT among Health Related SMEs in Nairobi, Kenya", International Journal of Arts and Commerce, 2 (3), 1-16.

- Mao H. , Liu SH., ZhangJ. (2014). "How the effects of IT and knowledge capability on organizational agility are contingent on environmental uncertainty and information intensity", Information Development, September.

- Martin, E., DeHayes, D., Hoffer, J. \& Perkins, W. (1991). Managing information technology: what managers need to know. New York: Macmillan.

- Masrek, M. N., Karim, N. S. A. and Hussein, R. (2007). "Investigating corporate intranet effectiveness: a conceptual framework", Information Management \& Computer Security,15 (3), 168183.

- Mata, J., Fuerst, L., and Barney, J. (1995). "Information technology and sustained competitive advantage: a resource-based analysis", MIS Quarterly,19 (4), 487-505.

- Maçada, A. C. G.; Beltrame, M. M., Dolci, P. C., Becker, João L.(2012). “IT Business Value Model for Information Intensive Organizations", Brazilian Administration Review (BAR), Vol. 9, No. 1, p. 44-65.

- McAfee, A. (2006). "Mastering the three worlds of information technology", Harvard Business Review, 84, and (11), 141-149.

- $\quad$ M de Chabert, J. (1998). "A model for the development and implementation of core competencies in restaurant companies for superior financial performance Unpublished doctoral dissertation, Virginia Polytechnic Institute and University

- Melville, N., Kraemer, K. and Gurbaxani, V. (2004). “Review: Information Technology and Organizational Performance: An Integrative Model of IT Business Value", MIS Quarterly, 28 (2), 283-322. 
- Mithas, S.; Ramasubbu, N.; Krishnan, M. S.; and Sambamurthy, V. (2005). "Information technology infrastructure capability and firm performance: An empirical analysis" Working Paper, Ross School of Business, University of Michigan, Ann Arbor, 2005 http://www.misrc.umn.edu/ workshops/2004/spring/sunil.pdf

- Narver, J. C. and Slater, S. F. (1990)."The Effect of a Market Orientation on Business Profitability," Journal of Marketing, 54 (4), 20-35,

- Nath, P. Nachiappan, S. \& Ramanathan, R. (2010). "The impact of marketing capability, operations capability and diversification strategy on performance: A resource-based view. Industrial", Marketing Management, 39 (2), 317-329. doi: 10.1016/j.indmarman.2008.09.001

- Newbert, S. L. (2008). "Value, rareness, competitive advantage, and performance: a conceptual-level empirical investigation of the resource-based view of the firm", Strategic Management Journal, 29(7), 745-768. http://dx.doi.org/10.1002/smj.686

- Nunnally, J. C. (1978). Psychometric Theory. ${ }^{\text {nd. }}$ ed. New York: McGraw-Hill.

- Orlikowski, W. \& lacono, C. S. (2001). "Research commentary: desperately seeking the "IT" in IT research -A call to theorizing the IT artifact", Information Systems Research, 12 (2), 121- 134.

- Panda, T. (2001). Strategic Advantage through Successful Co-branding. Faculty of Marketing, Indian Institute Management, pp. 1-10

- Parnell, J. A. (2011). “Strategic capabilities, competitive strategy, and performance among retailers in Argentina, Peru and the United States", Management Decision, 49 (1), 130-55.

- Peteraf, M. (1993). "The cornerstone of competitive advantage: a resource-based view", Strategic Management Journal, 14 (3), 179-191.

- Porter, M. (1985). Competitive Advantage Creating and Sustaining Superior Performance. New York: The Free Press.

- Porter, M.E. and Millar V. E. (1985). "How Information Gives You Competitive Advantage", Harvard Business Review, 63, (4), 149-160. " ",

- Powell, T. C. and Dent-Micallef, A. (1997). "Information Technology as Competitive Advantage: The Role of Human, Business, and Technology Resources", Strategic Management Journal, 18, (5), 375-405.

- Prithwiraj, N., Subramanian N., Ramakrishnan R. (2010). “The impact of marketing capability, operations capability and diversification strategy on performance: A resource-based view", Industrial Marketing Management, 39 (2), 317-329.

- Radhakrishnan, A.; Zu, X. and Grover, V. (2008). "A process-oriented perspective on differential business value creation by information technology: An empirical investigation", Omega: The International Journal of Management Science, 36(6), 1105-1125.

- Ranganathan, C.; Teo, T. and Dhaliwal, J. (2011). "Web-enabled supply chain management: Key antecedents and performance impacts", International Journal of Information Management, 31(6), 533-545.

- Ravichandran, T. and Lertwongsatien, C. (2005)." Impact of information systems resources and capabilities on firm performance: A resource-based perspective", Proceedings of $23^{\text {rd }}$ International Conference on Information Systems, 15-18 December, Barcelona, Spain, 577-582.

- Ray, G.; Barney, J. and Muhanna, W. (2004). “Capabilities, business processes, and competitive advantage: Choosing the dependent variable in empirical tests of the resource based view", Strategic Management Journal, 25,23-37

- Reich, B. H. and I. Benbasat. (2000). "Factors that influence the social dimension of alignment between business and information technology objectives", MIS Quarterly, 24(1), 81-111. 
- Ross, J.; Beath, C. and Goodhue, D. (1996). “Develop Long-Term Competitiveness Through IT Assets", Sloan Management Review, 38 (1), 31-42.

- Rouse M., Daellenbach, U. (1999). “Rethinking Research Methods for the Resource-based Perspective: Isolating sources of sustained competitive advantage", Strategic Management Journal, 20 (5), 487-494.

- Saqib, S. and Rashid, S. (2013). "Resource Based View of the Firm: The Nature of Resources Required for Competitive Advantage", International Journal of Management and Organizational Studies, 2 (1), 92-95.

- Slater, S. and J. Narver. (1994). “Does competitive environment moderate the market orientationperformance relationship?", Journal of Marketing, 58 (1), 46-55.

- Song, M.; Droge, C.; Hanvanich, S. \& Calantone, R. (2005). “Marketing and technology resource complementarity: An analysis of their interaction effect in two environmental contexts", Strategic Management Journal, 26 (3), 259-276.

- Tallon, P. (2007). Inside the adaptive enterprise: An information technology capabilities perspective on business process agility. Technical report, Centre for Research on Information Technology and Organizations, University of California, Irvine.

- Tallon, P. and Kraemer, K. (2003). Using Flexibility to Enhance the Alignment between Information Systems and Business Strategy: Implications for IT Business Value. Centre for Research on Information Technology and Organizations, Graduate School of Management, University of California, Irvine, CA 92697-4650.

- $\quad$ Thompson, A. A.; Gamble, J. E. \& Strickland, A. J. (2004). Strategy: Winning in the Marketplace. Boston, MA: McGraw-Hill Irwin.

- Tian, J.; Wang, Kanliang, C.; Yan Ch. and Björn J. (2009). “From IT Deployment Capabilities to Competitive Advantage: An Exploratory Study in China", Information Systems Frontiers, 12, (3), 239 255. Available at SSRN: http://ssrn.com/abstract=1323195

- Tippins, M. J. and Sohi, R. S. (2003). "IT competency and firm performance: are organizational learning a missing link?", Strategic Management Journal, 24,745-761.

- Turban, E. (2004). Information Technology for Management Transforming Organizations in the Digital Economy. $4^{\text {th }}$ Ed. Prentice Hall.

- Vorhies, D. W. \& Morgan, N. A. (2005). "Benchmarking marketing capabilities for sustained competitive advantage", Journal of Marketing, 69 (1), 80-94

- Wade, M.; Hulland, J. (2004)."The resource-based view and information systems research: review, extension, and suggestions for future research", MIS Quarterly, 28, (1), 107-142.

- Weill, P. and M. Vitale (2002). "What IT infrastructure capabilities are needed to implement ebusiness models?", MIS Quarterly, 1(1), 17-34.

- Weill P. and Vitale M., (1999). "Assessing the health of an information systems applications portfolio: an example from process manufacturing", MIS Quarterly, 23 (4), 601-624.

- Wernerfelt, B. (2011). "The use of resources in resource acquisition", Journal of Management, 37: 13691373.

- Wernerfelt, Birger. (1984). "A Resource-Based View of the Firm", Strategic Management Journal. $5,(2), 171-180$.

- Wiengarten, F.; Humphreys, P.; Cao G and McHugh, M. (2013) Exploring the Important Role of Organizational Factors in IT Business Value: Taking a Contingency Perspective on the Resource-Based View", International Journal of Management Reviews, 15, 30- 46. 
- Wiggins, Robert. (1997). "Sustaining Competitive Advantage: Temporal Dynamics and the Rarity of Persistent Superior Economic Performance", Presented at: The Annual Meeting of the Academy of Management, Boston, http://www.wiggo.com/CA97Acad.pdf

- Woodruff, R. B. (1997). "Customer value: the next source for competitive advantage", Academy of Marketing Science, 25 (2), 139-153.

- Yin G. Yang B. (2011) “The Construction of Firm's IT Capability and its Impact on IT Assimilation: An Emperical InvistigationinChina", Service Science, Vol. 2, No. 2, October.

- Zhang, M. and Sarker, S. (2008). "Unpacking the effect of IT capability on the performance of export-focused SMEs: a report from China", Information Systems Journal, 18 (4), 357-380.

- Zhang, M. J. (2005). “Information Systems, Strategic Flexibility, and Firm Performance: An Empirical Investigation", Journal of Engineering and Technology Managementm, 22 (3), 163-184.

- Zhang, M. J. (2007). "Assessing the performance impacts of information systems from the resource-based perspective: An empirical test of the indirect effect of IS", Journal of Business Strategies, $24(2), 141-164$.

- Zhenyu, Y. (2011). “Toward Digital Dynamic Capabilities: A Theoretical Exploration”, International"Journal of Electronic Commerce Studies, I2 (1), 1-18.

- Zhijun K. (2011). "IT Infrastructure, E-commerce Capabilities and Firm Performance: A Empirical Test Based on China Firm Data Chapter" Advanced Research on Computer Education, Simulation and Modelling. Series Communications in Computer and Information Science, 176, 79-85.

- Zhu, K. (2004). "The complementarity of information technology infrastructure and e-commerce capability: A resource based assessment of their business value", Journal of Management Information Systems, 21 (1), 167-202.

- Zhu K. and Kraemer K. L. (2005). "Post-adoption variations in usage and value of e-business by organizations: cross-country evidence from the retail industry", Information Systems Research, $16(1), 61-84$.

- Zhu K. Kraemer; K. Xu K., and Dedrick J., (2004). "Information Technology Payoff in E-Business Environments: An International Perspective on Value Creation of E-Business in the Financial Services Industry", Journal of Management Information Systems, Vol. 21, No. 1, pp. 17-54. 


\section{Appendix I}

Part One- Institution Name:

\section{The Managers' and Senior Staff Questionnaire}

Personal Information-Sex (Male- Female) - Age - Academic Qualification: Secondary School-College-Undergraduate-Postgraduate Organization Superior Performance

\begin{tabular}{|c|c|c|c|c|c|}
\hline $\begin{array}{l}\text { Please evaluate the performance of your business over the past } \\
\text { five years compared to your major competitors. }\end{array}$ & $\begin{array}{l}\text { Much } \\
\text { Better }\end{array}$ & Better & Equal & $\begin{array}{l}\text { Worse } \\
\text { Than }\end{array}$ & $\begin{array}{l}\text { Much } \\
\text { Worse }\end{array}$ \\
\hline 1. Market share growth. & & & & & \\
\hline 2. Growth in sales revenue. & & & & & \\
\hline 3. Institution profitability. & & & & & \\
\hline 4. The ability of client retention. & & & & & \\
\hline
\end{tabular}

\section{Information Intensity}

\begin{tabular}{|c|c|c|c|c|c|}
\hline To what extent you agree with the following statements? & $\begin{array}{c}\text { Strongly } \\
\text { Agree }\end{array}$ & Agree & $\begin{array}{c}\text { No } \\
\text { Opinion }\end{array}$ & Disagree & $\begin{array}{l}\text { Strongly } \\
\text { Disagree }\end{array}$ \\
\hline
\end{tabular}

1. Information is used to a great extent in our

2. production or service operations.

3. Information used in our production or service operations is frequently updated.

4. Information used in our production or service operations is usually accurate.

5. Many steps in our production or service operations require the frequent use of information.

\section{The Questionnaire for Information Technology Workers}

Part One- Institution Name:

Personal Information: Sex (Male-Female)-Age-Academic Qualification:Secondary School-College-Undergraduate-Postgraduate Organization Superior Performance

IT Capabilities

How does IT boost institution's performance in the following areas? Restrict your appraisal to value already realized rather than the value expected in the future.

\section{IT Infrastructure Capabilities (Functions)}

\begin{tabular}{|c|c|c|c|c|c|}
\hline \multicolumn{6}{|l|}{ Network Connectivity and Modularity of Software: } \\
\hline $\begin{array}{l}\text { To what extent do you agree with the following statements in } \\
\text { your institution? }\end{array}$ & $\begin{array}{l}\text { Strongly } \\
\text { Agree }\end{array}$ & Agree & $\begin{array}{c}\text { No } \\
\text { Opinion }\end{array}$ & Disagree & $\begin{array}{l}\text { Strongly } \\
\text { Disagree }\end{array}$ \\
\hline \multicolumn{6}{|l|}{ 1. Our systems are sufficiently flexible to link with external parties. } \\
\hline \multicolumn{6}{|l|}{ 2. Institution databases are accessed through many different protocols. } \\
\hline \multicolumn{6}{|l|}{$\begin{array}{l}\text { 3. Legacy systems within our institution do not hamper the de- } \\
\text { velopment of new IT applications. }\end{array}$} \\
\hline \multicolumn{6}{|c|}{ Compatibility of Hardware (Integration Capabilities) and IT Skills Adaptability: } \\
\hline \multicolumn{6}{|c|}{$\begin{array}{l}\text { 4. Our business is not limited by our choice of operating system } \\
\text { (e.g., UNIX, Windows...etc). }\end{array}$} \\
\hline \multicolumn{6}{|l|}{$\begin{array}{l}\text { 5. Software applications can be easily transported and used } \\
\text { across multiple platforms. }\end{array}$} \\
\hline \multicolumn{6}{|l|}{$\begin{array}{l}\text { 6. Our IT personnel has the ability to understand the priorities } \\
\& \text { objectives of the organization }\end{array}$} \\
\hline $\begin{array}{l}\text { 7. Our IT personnel can quickly develop technical solutions to } \\
\text { business problems. }\end{array}$ & & & & & \\
\hline
\end{tabular}




\section{IT Management Practice and Employee Empowerment Capabilities}

Coordination Capabilities:

To what extent do you agree with the following statements in your institution?

\begin{tabular}{|c|c|c|c|c|}
\hline $\begin{array}{c}\text { Strongly } \\
\text { Agree }\end{array}$ & Agree & $\begin{array}{c}\text { No } \\
\text { Opinion }\end{array}$ & Disagree & $\begin{array}{l}\text { Strongly } \\
\text { Disagree }\end{array}$ \\
\hline
\end{tabular}

1. IT reduces costs of coordinating of internal institution's activities.

2. IT reduces costs of coordinating of external institution's activities.

3. IT Provide more effective coordination among external and internal institution's activities.

\section{Process Planning and Support Capabilities:}

4. IT strengthens strategic planning.

5. IT enables your institution to adopt new institutional structures.

6. IT improves managerial decision-making.

\section{IT Strategic Capabilities:}

7. IT provides the institution advantages such as lower costs or product differentiation.

8. IT enhances the effectiveness of our overall performance.

9. IT creates barriers to keep competitors from entering our markets.

10. IT influences the buyer's decision to switch to service.

\section{IT Functional Capabilities}

IT Production and Operations:

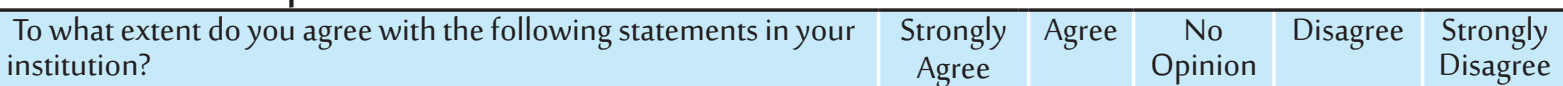

1. IT allows economies of scale for the service.

2. IT improves the quality of service.

3. IT increases the number of clients who can be served per employee.

Customer Relation and Service Enhancement Capabilities

\begin{tabular}{|c|c|c|c|c|c|}
\hline $\begin{array}{l}\text { To what extent do you agree with the following statements on IT } \\
\text { applications in your institution? }\end{array}$ & $\begin{array}{l}\text { Strongly } \\
\text { Agree }\end{array}$ & Agree & $\begin{array}{l}\text { No } \\
\text { Opinion }\end{array}$ & Disagree & $\begin{array}{l}\text { Strongly } \\
\text { Disagree }\end{array}$ \\
\hline
\end{tabular}

1. IT improves the efficiency through reducing the time \& cost of developing new services.

2. IT improves the institution's capability to reach clients at different geographic locations.

3. IT enhances the capabilities of the institution to respond to the needs of different clients differently.

Marketing Management Capabilities:

\begin{tabular}{|c|c|c|c|c|c|}
\hline $\begin{array}{l}\text { To what extent do you agree with the following statements in your } \\
\text { institution? }\end{array}$ & $\begin{array}{l}\text { Strongly } \\
\text { Agree }\end{array}$ & Agree & $\begin{array}{c}\text { No } \\
\text { Opinion }\end{array}$ & Disagree & $\begin{array}{l}\text { Strongly } \\
\text { Disagree }\end{array}$ \\
\hline \multicolumn{6}{|l|}{ 1. IT helps track market response to pricing strategies. } \\
\hline \multicolumn{6}{|l|}{ 2. IT enables sales people to increase sales per client. } \\
\hline \multicolumn{6}{|l|}{ 3. IT improves accuracy of sales forecasts. } \\
\hline \multicolumn{6}{|l|}{ 4. IT helps track market response to advertising campaigns. } \\
\hline \multicolumn{6}{|l|}{ Suppliers Partnership/Collaboration: } \\
\hline $\begin{array}{l}\text { To what extent do you agree with the following statements on IT } \\
\text { applications in your institution? }\end{array}$ & $\begin{array}{l}\text { Strongly } \\
\text { Agree }\end{array}$ & Agree & $\begin{array}{c}\text { No } \\
\text { Opinion }\end{array}$ & Disagree & $\begin{array}{l}\text { Strongly } \\
\text { Disagree }\end{array}$ \\
\hline \multicolumn{6}{|l|}{ 1. IT helps the institution get better services from their suppliers \partnership. } \\
\hline \multicolumn{6}{|l|}{$\begin{array}{l}\text { 2. IT helps the institutions to develop close relationships with sup- } \\
\text { pliers } \backslash \text { partnership. }\end{array}$} \\
\hline \multicolumn{6}{|l|}{ 3. IT applications enable electronic transactions with supplier $\backslash$ partnership } \\
\hline \multicolumn{6}{|l|}{ IT Financial Capabilities: } \\
\hline $\begin{array}{l}\text { To what extent do you agree with the following statements in your } \\
\text { institution? }\end{array}$ & $\begin{array}{l}\text { Strongly } \\
\text { Agree }\end{array}$ & Agree & $\begin{array}{c}\text { No } \\
\text { Opinion }\end{array}$ & Disagree & $\begin{array}{l}\text { Strongly } \\
\text { Disagree }\end{array}$ \\
\hline \multicolumn{6}{|l|}{ 1. IT reduces the required time to prepare financial reports. } \\
\hline \multicolumn{6}{|l|}{ 2. IT helpsyour institution to prepare different special financial reports. } \\
\hline 3. IT helps reduce the costs of preparing financial reports. & & & & & \\
\hline
\end{tabular}

